\title{
Results of the Quarterly Tritium Survey of Fourmile Branch and Its Seeplines in the F \& H Areas of SRS: December 1994
}

by

J. W. Koch II

Westinghouse Savannah River Company

Savannah River Site

Aiken, South Carolina 29808

K. L. Dixon

B. B. Looney

This paper was prepared in connection with work done under the above contract number with the U.S.

Department of Energy. By acceptance of this paper, the publisher and/or recipient acknowledges the U. $S$. Government's right to retain a nonexclusive, royalty-free license in and to any copyright covering this paper, along with the right to reproduce and to authorize others to reproduce all or part of the copyrighted paper. 


\section{DISCLAIMER}

This report was prepared as an account of work sponsored by an agency of the United States Government. Neither the United States Government nor any agency thereof, nor any of their employees, makes any warranty, express or implied, or assumes any legal liability or responsibility for the accuracy, completeness, or usefulness of any information, apparatus, product, or process disclosed, or represents that its use would not infringe privately owned rights. Reference herein to any specific commercial product, process, or service by trade name, trademark, manufacturer, or otherwise does not necessarily constitute or imply its endorsement, recommendation, or favoring by the United States Government or any agency thereof. The views and opinions of authors expressed herein do not necessarily state or reflect those of the United States Government or any agency thereof.

This report has been reproduced directly from the best available copy.

Available to DOE and DOE contractors from the Office of Scientific and Technical Information, P. O. Box 62, Oak Ridge, TN 37831; prices available from (423) 576-8401.

Available to the public from the National Technical Information Service, U. S. Department of Commerce, 5285 Port Royal Road, Springfield, VA 22161. 


\section{DISCLAIMER}

Portions of this document may be illegible electronic image products. Images are produced from the best available original document. 


\section{"NNFORMATION ONLY"}

WSRC-TR-95-0300

Rev 0

\section{Results of the Quarterly Tritium Survey of Fourmile Branch and its Seeplines in the F- and H-Areas of SRS: December 1994 (U)}

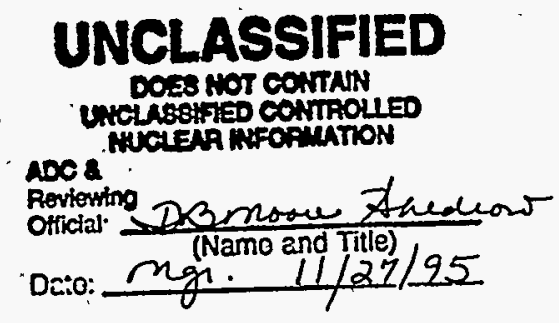

Westinghouse Savannah River Company Savannah River Site Aiken SC 29808 
WSRC-TR-95-0300

Rev 0

December 1994

\section{Results of the Quarterly Tritium Survey of Fourmile Branch and its Seeplines in the F-and H-Areas of SRS: December 1994 (U)}

J. W. Koch II and K. L. Dixon

Prèpared for the U. S. Department of Energy under contract no. DE-AC09-89SR18035 


\title{
Results of the Quarterly Tritium Survey of Fourmile Branch and its Seeplines in the F-and H-Areas of SRS: December 1994
}

\author{
J. W. Koch II and K. L. Dixon
}

\section{Abstract}

The Environmental Sciences Section (ESS) of the Savannah River Technology Center (SRTC) established a quarterly monitoring program of the Fourmile Branch (FMB) stream and its associated seepline located down gradient from the F- andH-Area Seepage Basins. The primary focus of this program was to survey and track changes in tritium levels; however, specific conductivity, and $\mathrm{pH}$ were also surveyed and tracked. The measurements from the tenth scheduled survey (December 1994) exhibited similar tritium levels, conductivity measurements, and $\mathrm{pH}$ values to data from previous sampling events. The overall results of the tritium survey and stream monitoring data (Looney et al., 1993) indicates that the tritium plume resulting. from the operation of the seepage basins continues to flush from the Fourmile Branch wetland system.

\section{Executive Summary}

In December 1994 the Environmental Sciences Section (ESS) surveyed the Fourmile Branch seepline down gradient from the $\mathrm{F}$ - and H-Area Seepage Basins for tritium, specific conductivity, and $\mathrm{pH}$. The survey was the tenth quarterly. survey scheduled to monitor the movement of contaminants from the basins since certified closure in 1991. Surface-water samples were collected from 60 locations along the seepline and from three stream locations along. Fourmile Branch. The seepline locations included 22 from F Area, 22 from $\mathrm{H}$. Area, and 16 from the seepline south of $643-E$, which is. a decommissioned area in the Solid Waste Disposal Facility. Forty-four of the locations were sampled in 1989. by the Savannah River Laboratory (now Savannah River Technology Center) as part of an extensive characterization study (Haselow et al., 1990). ESS found that tritium activities in both $\mathrm{F}$ - and H-Area seeplines in December 1994 were. significantly lower than the activities measured by Haselow et al. (1990). Only 5 locations showed à significant increase in tritium activity above the March 1989 results.

Previous sampling events have consistently shown a declining trend in tritium activity at the F- and H-Area. seepline. Total tritium fluxes to the wetlands and FMB have steadily declined since basin closure (Looney et al., 1993) and overall results from the tritium survey support this finding. Differences in tritium activities measured at individual seepline sampling locations from one sampling event to the next represent seasonal variability in depth to water table, variable amounts of rainfall, as well as. changes due to the flushing of the plume from the wetland system. Conclusions about tritium fluxes to the wetlands and FMB.should consider the long-term surface water, seepline, and groundwater monitoring data and not rely on quarterly changes in concentrations at seepline monitoring stations alone.

December 1994 conductivity measurements exhibited the same general trends as tritium activities in both $\mathrm{F}$ and $\mathrm{H}$ Areas.' The average concentrations of hydrogen ions decreased slightly in both areas and is close to normal for this type of wetland. Aluminum concentrations measured along the seepline in 1989 (Haselow et al., 1990) were high enough to be potentially toxic to plants. Increases in $\mathrm{pH}$ reduce the solubility of aluminum and thereby decrease the potential for aluminum toxicity to plants. . Concentrations of aluminum, as well as other metals, measured along the seepline in July 1992 were substantially lower than 1989 concentrations reflecting the increase in $\mathrm{pH}$ (Dixon and Rogers, 1993e). Field observations have revealed that vegetation in all areas is showing noticeable recovery.

The seepline south of 643-E, along a tributary of Fourmile Branch, is influenced by tritium migrating from the Burial Ground Complex. The tributary (old F-Area effluent ditch) is a natural drainage that received effluent discharge from F-Area Separations prior to the construction of the engineered effluent canal. December 1994 tritium activities ranged from 25 to $907 \mathrm{pCi} / \mathrm{mL}$ on the east side of the drainage and from 315 to 36,383 
$\mathrm{pCi} / \mathrm{mL}$ on the west side. The tritium activity measured in the stream of the natural drainage was $18,738 \mathrm{pCi} / \mathrm{mL}$. Results suggest that the tritium outcrop area has been delineated by the sampling locations established on the west side of the drainage channel. While the tritium activity shifts slightly among sample locations there has been no indication that there has been a reduction in overall tritium activity. Conductivity and $\mathrm{pH}$ measurements taken on both sides of the drainage were similar to those recorded in September and were within the range of normal values for this wetland. The low conductivity values measured along the drainage way suggest that the tritium plume outcropping in the area emanates from 643E. This is because wastes introduced into $643-\mathrm{E}$ contained low levels of salt ions compared to the waste introduced into the $\mathrm{F}$ - and $\mathrm{H}$-Area bàsins.

\section{Introduction}

Seepage basins in the $\mathrm{F}$ and $\mathrm{H}$ Areas of SRS received low-level radioactive waste effluent from the chemical separation processes in the general separation areas. The basins retained the effluent to slowly release it into the soil. The waste effluent consisted principally of sodium hydroxide, nitric acid, low levels of various radionuclides, and some metals (Killian - et al., 1985a and 1985b). Discharges of tritiated water to the seepage basins accounted for most of the radioactivity (Fenimore and Horton, 1972).

The Savannah River Laboratory (now the Savannah River Technology Center) conducted an extensive study designed to characterize the shallow groundwater outcropping into Fourmile. Branch (FMB) and its associated seepline in 1988 and 1989 (Haselow et al., 1990). As a part of this study, Haselow et al. (1990) surveyed for tritium, $\mathrm{pH}$, and conductivity. Researchers found low $\mathrm{pH}$ and elevated conductivity and tritium. values along the seeplines and concluded that contaminants leaching from the F- and $\mathrm{H}$-Area seepage basins were impacting the wetlands below the basins. SRS stopped discharges to the Seepage Basins in 1988 and capped and sealed the basins in 1990 to eliminate the source of .contaminants. Scientists hypothesized that after the elimination of the contaminant source, annual rainfall and natural groundwater flow would flush the remaining contaminant plume out of the shallow groundwater over time. After the contaminant plume in "the shallow groundwater is flushed out, the impacted wetland systems immediately down gradient - from the basins should recover.
To investigate this hypothesis, a quarterly sampling program was established in May, 1992. ESS sampled 44 of the seepline locations sampled by Haselow et al.; (1990) for tritium, $\mathrm{pH}$, and specific conductivity. The Haselow et al. (1990) results established the baseline to which the results from the quarterly sampling program are compared. These collection points were chosen as the baseline because they are the only data available that were collected before the basin discharges were discontinued. The Haselow et al. (1990) data should be representative of conditions immediately prior to closing the basins. This sampling program is intended to complement the semi-annual sampling of the seepline for 'selected Appendix IX constituents, which began in July" 1992. A report summarizing results from the semi-annual sampling program has been completed (Dixon and Rogers, 1993e).

There was expressed concern about the source of tritium and other contaminants that possibly. emanate from an. area in the southwest comer of $643-\mathrm{E}$ rather than from the closed basins. To investigate this possibility, numerous sampling locations on the H-Area seepline south of 643-E were established and have been incorporated into the quarterly sampling plań.

\section{Methods}

ESS conducted the tenth sampling: for the quarterly tritium survey in December 1994. Sampling locations were the same as those selected in the ninth round of sampling. These locations, according to 1989 data, exhibited high and low values for the three variables of concern. Attempts were made to establish even ground coverage along both seeplines. ESS collectëd 60 samples from the seeplines in F and H Area: 22 from the F-Area seepline, 22 from the H-Area seepline, and 16 from the seepline south of 643-E Area. One sample was taken from the old F-Area effluent ditch. ESS also collected three stream samples from locations on Fourmile Branch. Figures 1 and 2 show approximate sampling point locations.

Prior to sampling for the first quarter in May 1992, the Health Protection Department (HPD) collected soil samples from several locations along both seeplines and monitored them for gamma radioactivity. HPD did not detect gamma elevated radiation; therefore, ESS selected rubber boots and disposable rubber gloves as protective clothing to prevent dermal contact with seepline water during sampling operations. 
Results of the Quarterly Tritium Survey of Fourmile Branch and its Seeplines in the F and H Areas of SRS: December 1994

Seepline sampling locations had been previously marked and labeled with PVC stakes. Samples were collected within a three foot radius of the PVC stake by boring a hole into' the soil with a small soil bucket auger, generally six inches and not more than eighteen inches deep to obtain sample. To collect water for tritium analysis, polyethylene sample containers $(25 \mathrm{~mL})$ were dipped into. the water until full 'and then capped. The outside of each container was then rinsed with deionized water and sealed in a small polyethylene bag to minimize the possibility of contamination. The small bags were then sealed in a large polyethylene bag. The Environmental Monitoring Section (EMS) performed tritium analysis (total activity). EMS counted $5 \mathrm{~mL}$ aliquots for 20 minutes, which yielded a lower detection limit of $1.3, \mathrm{pCi} / \mathrm{mL}$ (WSRC-3Q1-4, 1992).

ESS measured specific conductivity and $\mathrm{pH}$ in situ with conductivity and pH electrodes (WSRC-L14.1, 1992a and 1992b). The electrodes were rinsed with deionized water after each sampling. All sampling equipment was thoroughly rinsed with deionized water at the end of each day.

\section{Results and Observations}

Values of parameters measured at seepline sampling locations fluctuate throughout the year. Climatic and seasonal conditions, especially rainfall amounts influence' measured concentrations. Seepline measurements are made on water collected from fixed locations at the distal end, or toe outcrop, of the contaminant plume. Because the plume is dynamic (i.e., influenced by weather and other activities in the area) seepline monitoring is sensitive to both long term changes and seasonal/transient influences. Groundwater flow paths in F and H Area are complex, as illustrated in Figures 3 and 4. Recharge to the groundwater is primarily due to infiltration of rainwater (rainfall minus runoff and evapotranspiration). Groundwater then moves laterally to Fourmile Branch . and its tributaries.

As the water travels toward the stream, additional infiltration forces up-gradient water deeper. Near the stream, the flow lines rise to the surface, emerging between the seepline and the stream (which acts as the groundwater "drain"). This typical vertical trajectory, a path curving downward near the groundwater divide and then upward into draining surface water, is shown as flow lines on Figures 3 and 4.
Figure 3 shows the flow lines without contaminated water from the seepage basins and Figure 4 shows the addition of contaminated flow lines resulting from operations of the basins. The theoretical plume geometry is clearly confirmed by the real vertical profile of the F-Area Seepage Basin plume based on the detailed grid wells available in the 1970s (Looney et al., 1993). Changes in the water balance in the area influence the flow velocity. and tend to move the plume either deeper or shallower and cause the location of the contaminated water to move. This is especially importanit to data interpretation if the "toe" of the plume is shifting relative to the fixed sample locations. Figure 5 summarizes the projected changes in the plume based on a range of transient activities. Increased rainfall (or other activities "that increase infiltration such as harvesting trees) result in increased plume velocity and movement downward and away from the seepline. This decreases contaminant concentrations at the seepline sampling locations. Reduction in infiltration decreases plume velocity and causes the plume to move upward and closer to the seepline. This results in increased contaminant concentrations as measured at the seepline sampling locations.

Low rainfall for a few months prior to sampling increases constituent concentrations, and high rainfall decreases constituent concentrations in the shallow groundwater at the seepline intercept. Rainfall measured at SRS at the weather station in F Area for January through December 1994 was $125.2 \mathrm{~cm}$. From 1960 to 1991, the average rainfall measured in F Area for this same period was $124.4 \mathrm{~cm}$. Figure 6 shows a comparison of 1994 rainfall to the long term average (1960-1991). This indicates that average rainfall in the area was normal for the year.

. Figures 7 through 12 show comparisons of March 1989 with September and December 1994 tritium, conductivity, and $\mathrm{pH}$ measurements for locations in $\mathrm{F}$ - and H-Area seepline. Data for the first nine surveys can be found in Dixon and Rogers (1992, 1993a, 1993b, 1993c, 1993d and 1993e, and 1994), and Rogers et al. (1994a, 1994b, and 1994c). Figures 13 through 15 show the data for the Fourmile Branch stream locations. Figures 16 through 18 show the data for the sampling locations along the old effluent seepline and include one stream sample from the branch channel south of 643-E. These sampling locations were identified with the prefix FHB. 
Results of the Quarterly Tritium Survey' of Fourmile Branch and its Seeplines in the F and H Areas of SRS: December 1994

was used to investigate the correlation of $\mathrm{H}$ Area tritium activities and conductivity values. The probability that the two parameters exhibited independent trends was zero. The rank correlation coefficient $\left(r_{s}=0.78\right)$ for $H$ Area was less than that for $\mathrm{F}$ Area, but still suggested a good correlation.

\section{F- and H-Area Seepline pH Meásurements}

F- Area pH values ranged from 3.6 to 6.0 with an average value of 4.9 (Figure 11 and Table 2). H- Area $\mathrm{pH}$ values ranged from 4.6 to 6.6 with an average of 5.8 (Figure 12 and Table 3). The $\mathrm{pH}$ for the entire seepline ( $\mathrm{F}$ and $\mathrm{H}$ Areas combined) averaged 5.3. The average is 0.4 units over the 4.9 average in 1989 (Haselow et al., 1990). An increase in pH will affect the solubility of metals in the soil which should improve the soil water chemistry and enhance the recovery of wetland vegetation stressed indirectly by low $\mathrm{pH}$. Aluminum concentrations measured along the seepline in 1989 (Haselow et al., 1990). were . high enough to be toxic to plants. Increases in $\mathrm{pH}$ from an average of 4.9 in 1989 to 5.3 have reduced the amount of aluminum in solution and thereby reduced it as a possible source of plant toxicity. Concentrations of aluminum and other metals measured along the seepline in July 1992 were substantially lower than 1989 concentrations, 'reflecting the effects of the increase in $\dot{\mathrm{p}} \mathrm{H}$ (Dixon and Rogers, 1993e). Field observations have revealed that vegetation in all of the stressed areas is making noticeable recovery (Nelson and Irwin, 1994).

\section{Fourmile Branch Measurements}

Figures 13 through 15 show the tritium, conductivity, and $\mathrm{pH}$ values for the Fourmile Branch stream sampling locations. Table 4 provides the data used in the figures. Tritium activities at these locations ranged from 59 to 312 $\mathrm{pCi} / \mathrm{mL}$. These results were consistent with those from previous sampling events and show increases in tritium. down stream as the seepline water enters the channel of Fourmile Branch. Conductivity measurements ranged from 61 to $80 \mu \mathrm{S} / \mathrm{cm}$ and $\mathrm{pH}$ ranged from 5.3 to 5.4. Both conductivity and $\mathrm{pH}$ values were at near normal levels.

\section{Solid Waste Disposal Facility (643-E) Seepline - Measurements}

The graphs in Figures 16 through 18 show tritium, conductivity, and $\mathrm{pH}$ values for the seepline and stream sampling locations south of 643-E, which is part of the Solid Waste Disposal Facility. Table 5 provides the data used in the figures. This seepline is along the natural drainage (old F-Area effluent ditch) that was used to discharge effluent from F-Area separations prior to the construction of the engineered effluent canal.

Tritium activities for the locations on the east side of the drainage ranged from 25 to $907 \mathrm{pCi} / \mathrm{mL}$. Activities on the west side of the drainage ranged from 315 to 36,383 $\mathrm{pCi} / \mathrm{mL}$ The tritium activity at the stream location in the drainage (FHB012) was $18,738 \mathrm{pCi} / \mathrm{mL}$.

Conductivity measurements on both sides of the drainage I were near background at most locations and ranged from 32 to $187 \mu \mathrm{S} / \mathrm{cm}$. Conductivity values are typical of the conductivity values being reported in the water table wells in the vicinity of the old F-Area effluent ditch (EMS, 1993). Using the Spearman rank.correlation test, no correlation $\left(r_{s}=-0.03\right)$ was found between conductivity and tritium for these locations. The $\mathrm{pH}$ values ranged from 4.1 to 5.8 with an average of 5.4.

These results are consistent with the Haselow et al. (1990) results for the western portion of the H-Area seepline, particularly near location HSP103. Haselow et al. (1990) found that down gradient from $643-\mathrm{E}$, conductivity values were near background while tritium concentrations were elevated. This was attributed to tritiated wastes deposited in 643-E. Tritium activities measured along the seepline down gradient of 643-E (particularly sample points on the west side) suggest that tritium migrating from $643-\mathrm{E}$ and outcropping in this area is substantial. The appearance of tritium on the west side as opposed to the east side of the drainage suggests that soil material placed in the northern reaches of the natural drainage forced the tritium plume to outcrop down gradient. It appears that the ground water containing tritium is moving below the fill material and outcropping on the west side of the drainage channel. The results suggest that the sampling locations on the west side of the drainage have delineated the tritium plume with the center located at or near FHB018.

\section{Conclusions}

Tritium concentrations measured at most locations during December 1994 ręmained relatively unchanged compared to previous sampling events. These results vary only slightly from previous sampling events and are attributed to seasonal water table change along with the dynamic nature of the groundwater tritium plume movement. Total tritium . fluxes to the wetlands and FMB have steadily $\because$ declined since basin closure (Looney et al., 1993) and overall results from the tritium survey support this finding. These findings support the hypothesis that the tritium plume in $F$ and $\mathrm{H}$ Area is being flushed from the 
shallow" groundwater. "Differences in " tritium concentrations measured at seepline sampling locations from one sampling event to the next represent seasonal' and rainfall variability as well as changes due to flushing of the contaminant plume from the wetland system. No correction has been made for tritium decay because of the short time between sampling events. Conclusions about tritium fluxes to the wetlands and FMB should consider the complexity of the ground water system and should be based on long-term surface water; seepline, and ground water monitoring data and not on quarterly changes in concentrations at seepline monitoring locations

Evaluation of data from 16 seepline locations south of the 643-E Area indicates that tritium migrating from $643-\mathrm{E}$ is outcropping at the old F Area effluent ditch, particularly on the west side of the stream channel. It appears that sampling locations on the west side of the channel have delineated the tritium outcrop area, with the present climatic and hydrologic conditions. Results do not indicate that the tritium plume has decreased over the past sampling events. The lack of decrease in tritium concentration supports the assumption that the source of tritium is coming from $643-\mathrm{E}$ rather than the capped basins.

\section{References}

Daniel, W.W: 1978. Applied Nonparametric Statistics. Houghton Mifflin Company, Boston; MA.

Dixon, K.L. and V.A. Rogers. 1992. Results of the First Quarter Tritium . Survey of the F- and H-Area Seeplines: ' May ' 1992.' WSRC-TR-92-304, Westinghouse Savannah River Company, Savannah River Technology Center, Aiken, SC.

Dixon, K.L. and V.A. Rogers. 1993a. Results of the Second Quarter Tritium Survey of the F- and H-Area Seeplines: September 1992. WSRC-TR-93-129, Westinghouse Savannah River Company, Savannah River Technology Center, Aiken, SC.

Dixon, K.L. and V.A. Rogers. 1993b. Results of the Third Quarter Tritium Survey of the F- and H-Area Seeplines: December 1992. WSRC-TR-93-284, Westinghouse Savannah River Company, Savannah River Technology Center, Aiken, SC.

Dixon; K.L. and V.A. Rogers. 1993c. Results of the Fourth Quarter Tritium. Survey of the F- and H-Area
Seeplines: March/April 1993. WSRC-TR-93-526, Westinghouse Savannah River Company, Savannah River Technology Center, Aiken, SC.

Dixon, K.L. and V.A. Rogers. 1993d. Results of the Quartérly Tritium Survey of Fourmile Branch and Its Seeplines in the F- and H-Areas of SRS: June 1993. WSRC-TR-93-656, Westinghouse Sầvannah River Company, Savannah River Technology Center, Aiken, SC.

Dixon, K.L. and V.A. Rogers. 1993e. Semi-Annual Sampling of Fourmile Branch and Its Seeplines in the F and H Areas of SRS: July 1992. WSRC-TR-93289, : Westinghouse Savannah River : Company, Savannah River Technology Center, Aiken, SC:

Dixon, K.L., and V.A. Rogers, and B. B. Looney. 1994. Results of the Quarterly Tritium Survey of Fourmile Branch and its Seeplines in the $F$ and $H$ Areas of . SRS: September 1993 (U) WSRC-TR-94-0286-ESS, Westinghouse Savannah River Company, Savannah River Technology Center, Aiken, SC.

Rogers, V.A., K.L. Dixon, and B.B. Looney: 1994. Results of the Quarterly Tritium Survey of Fourmile Branch and its Seeplines in the $F$ and $H$ Areas of SRS: December. 1993. (U) WSRC-TR-94-0342, Westinghouse Savannah River Company, Savannah River-Technology Ċenter, Aiken, SC.

Rogers, V.A., K.L. Dixon, and B. B. Looney. 1994. Results of the Quarterly Tritium Survey of Fourmile Branch and its Seeplines in the F and $\mathrm{H}$ Aeas of SRS: March 1994. (U) WS RC-TR-94-0408, Westinghouse Savannah River Company,- Savannah River Technology.Center, Aiken, SC.

Rogers; V.A., K.L. Dixon, and B. B. Looney. 1924. Results of the Quarterly Tritium Survey of Fourmile Branch and its Seeplines in the F and $\mathrm{H}$ Aeas of SRS: June 1994. (U) WSRC-TR-94-0441, Westinghouse Savannah River Company, Savannah River Technology Center, Aiken, SC.

Rogers, V.A., K.L. Dixon, and B.B. Looney. 1994. Results of the Quarterly Tritium Survey of Fourmile Branch and its Seeplines in the F and $H$ Areas of SRS: September 1994. (U) WSRC-TR-94-0536, Westinghouse Savannah River Company, Savannah River Technology Center, Aiken, SC. 
Results of the Quarterly Tritium Survey of Fourmile Branch and its Seeplines in the F and H Areas of SRS: December 1994.

Nelson, E,A.and Irwin, J.E. 1994. Current Vegetation . Characteristics within Tree-Kill Zones of $F_{-}$and $H$ Areas (U) WSRC-TR-94-0203 Westinghouse Sayannah , River .Company, Savannah River Technology Center, Aiken, SC.

Environmental Monitoring Section. 1993. The Savannah River Site's Ground water Monitoring Program, Second Quarter Report. ESH-EMS-930097, Westinghouse Savannah River Company, Aiken SC.

Fenimore, J.W. and J.H. Horton. 1972. Rating History and Environmental Effects of Seepage Basins in Chemical Separations Areas of the Savannah River Plant. DPST-72-548, E.I. du Pont de Nemours' and Company, Savannah River Laboratory, Aiken, SC.

Haselow, J.S., M. Harris, B.B. Looney, N.V. Halverson, and J.B. Gladden. 1990. Analysis of Soil and Water at the Fourmile Branch Seepline Near the $F$ and $H$ Area of SRS (U). WSRC-RP-90-0591, WSRC-TR92-304, Westinghouse Savannah River Company, Savannah River Technology Center, Aiken, SC. Savannah River Laboratory, Aiken, SC.

Killian, T.H., N.L. Kolb, P. Corbo, and I:W. Marine. 1985a. F-Area Seepage Basins. DPST-85-704, E.I. du Pont de Nemours and Company, Savannah River Laboratory, Aiken, SC.

Killian, T.H., N.L. Kolb, P. Corbo, and I.W. Marine. 1985b. H-Area Seepage Basins. DPST-85-706, E.I. du Pont de Nemours and Company, Savannah River Laboratory, Aiken, SC.

Looney, B.B., J.S. Haselow, C.M. Lewis, M.K. Harris, D.E. Wyatt, C.S. Hetrick. 1993. Projected tritium . releases from $F \& H$ Area seepage basins and the Solid Waste Disposal Facilities to Fourmile Branch (U): WSRC-RP-93-459, Westinghouse Savannah River Company, Savannah River Technology Center, Aiken, SC. Savannah River Laboratory, Aiken, SC.

WSRC-3Q1-4. 1992. Determination of Tritium in Water. Prócedure 2760, Rev 0. Westinghouse Savannah River Company, Aiken, SC.

WSRC-L14.1. 1992a. Procedure - for Cole-Parmer Portable Conductivity Meter Model 1481-40. Procedure 2-79, Rev 1. Westinghouse Savannah River Company, Aiken, SC
WSRC-L14.1. 1992b. Procedure for Cole-Parmer Model 5985-80 pH Meter. Procedure 2-81, Rev 1. Westinghouse Savannah River Company, Aiken, SC. 
$1-\cdots, \cdots$ WSRC-TR-0300

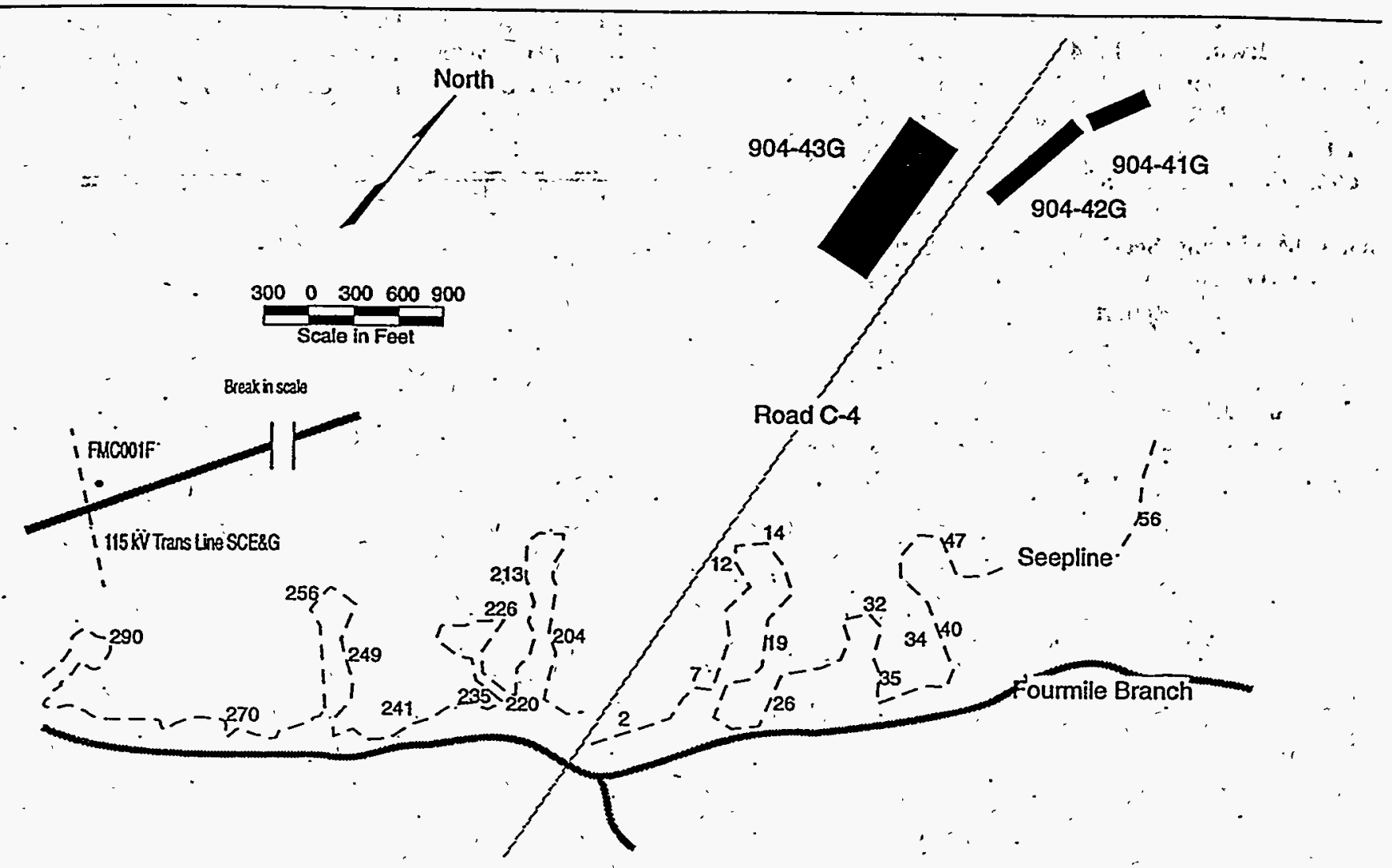

Figure 1. Location of F-Area Seepage Basins and Seepline Sampling Points
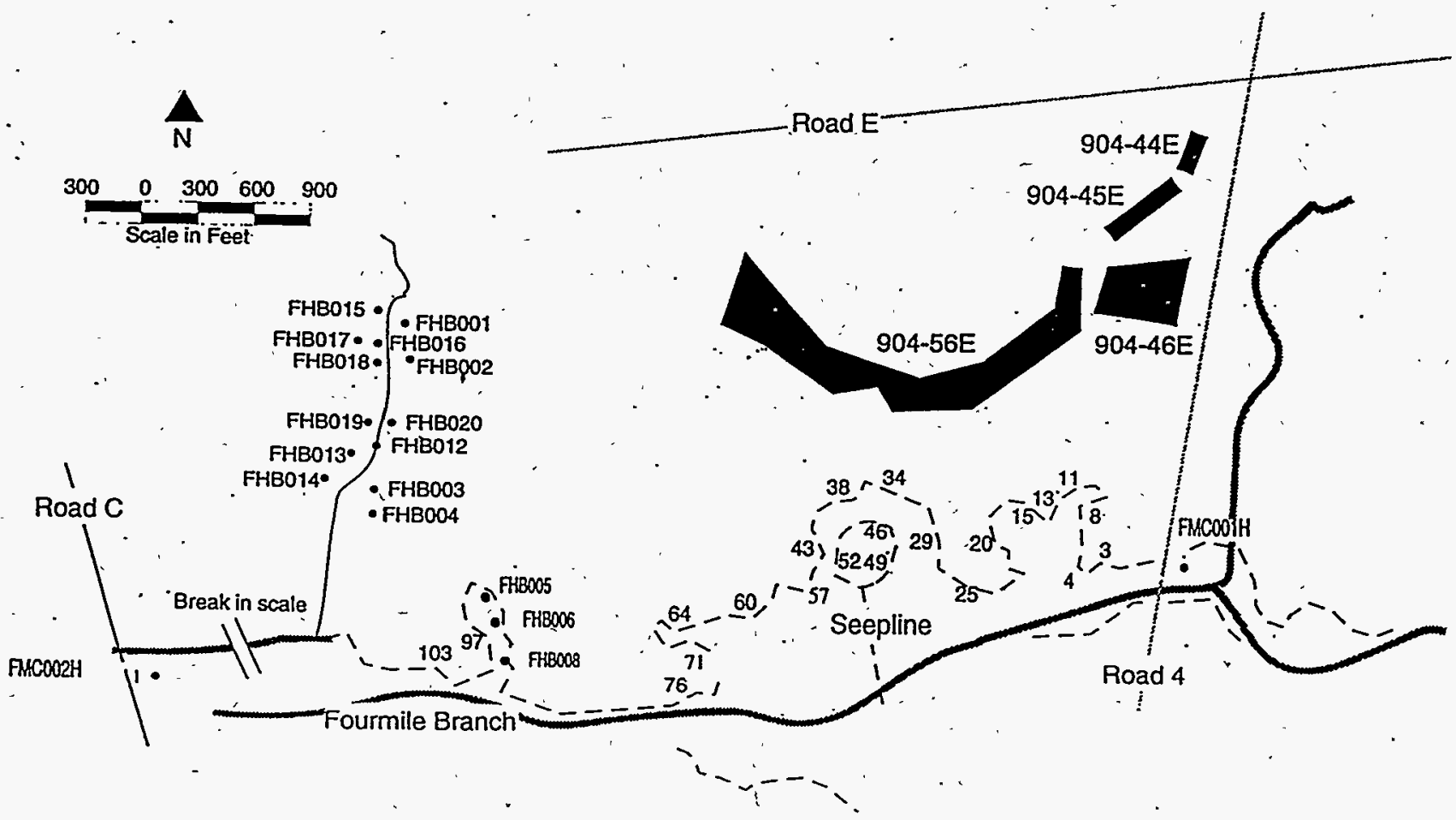

Figure 2. Location of H-Area Seepage Basins and Seepline Sampling Points and FHB Sampling Points 


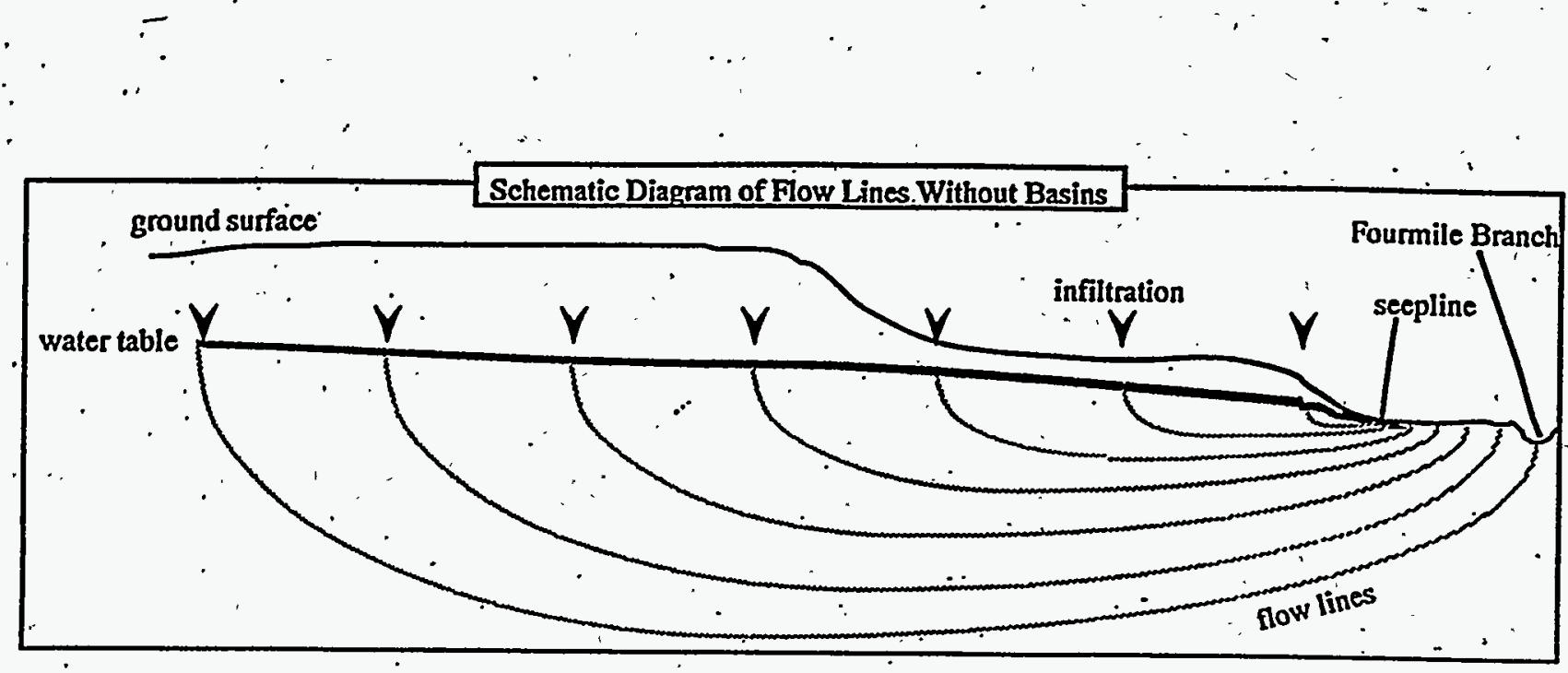

Figure 3. Schematic Diagram of Flow Lines in the Shallow Groundwater at the F-and H-Arca without Seepage Basins

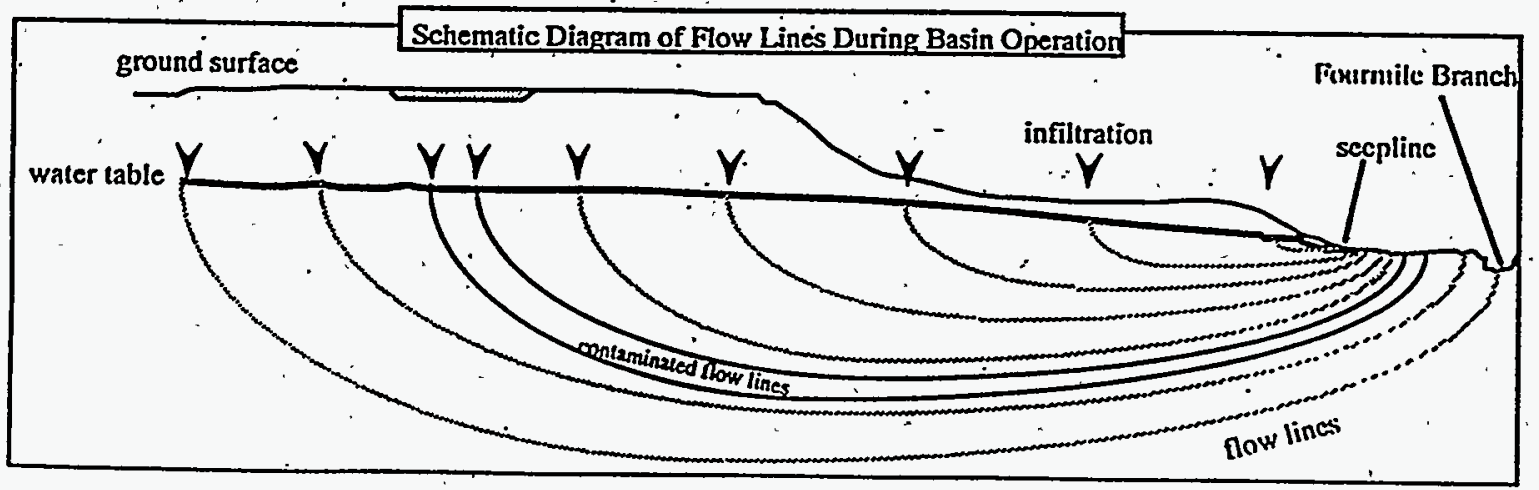

Figure 4. Schematic Diagram of Flow Lines in the Shallow Groundwater at the F- and H-Arca Scepline during Basin Operation 

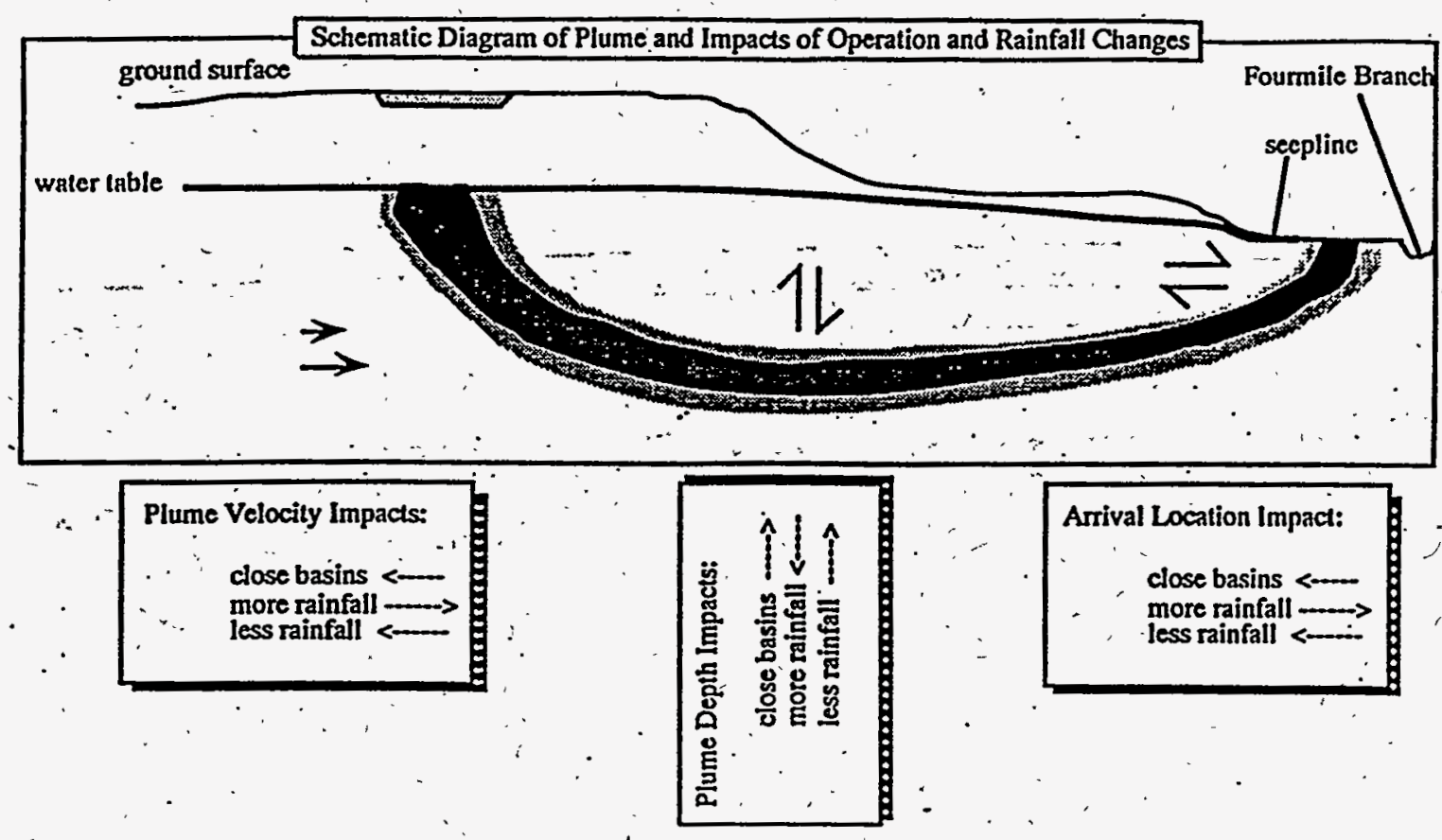

-Figure 5. Schematic of the Tritium Plume Migrating from F- and H-Area Seepage Basins

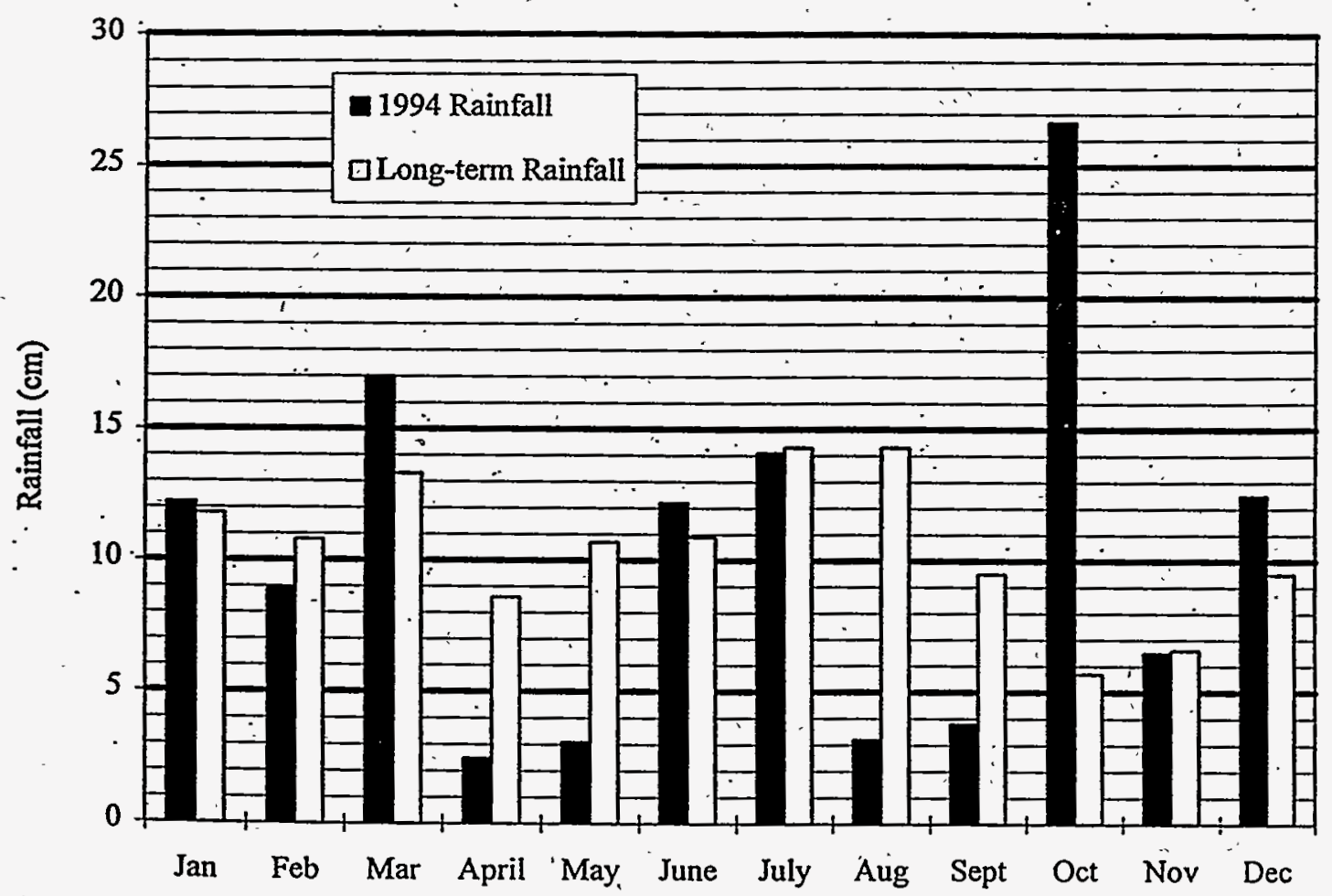

Figure 6. Comparison of 1994 Monthly Rainfall Totals to the Long-Term Average (1960-1991) for the F-Area Weather Station 
Results of the Quarterly Tritium Survey of Fourmile Branch and its Seeplines in the F and H.Areas of SRS: December 1994

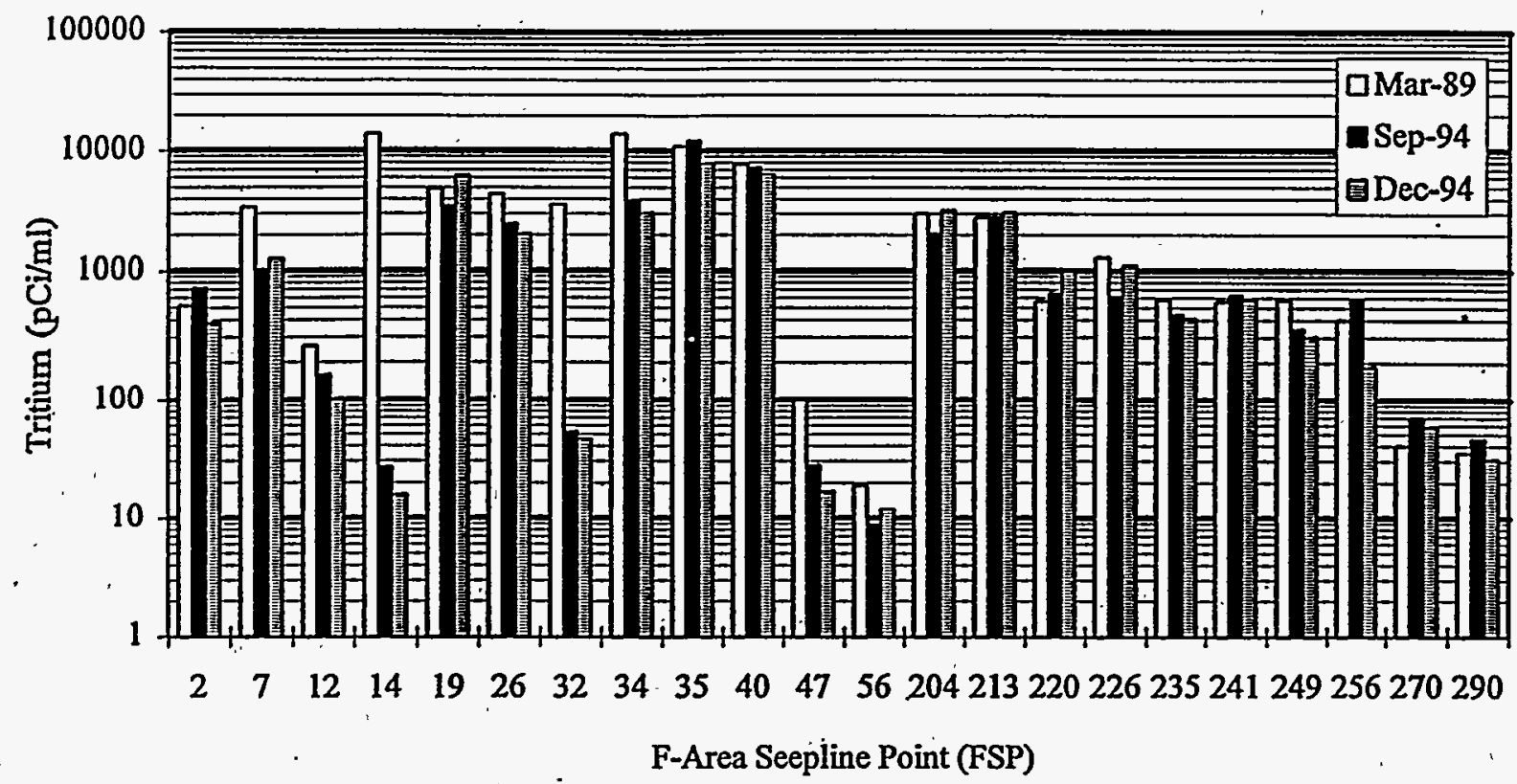

Figure 7. Comparison of Tritium Concentrations for Selected F-Area Seepline Locations

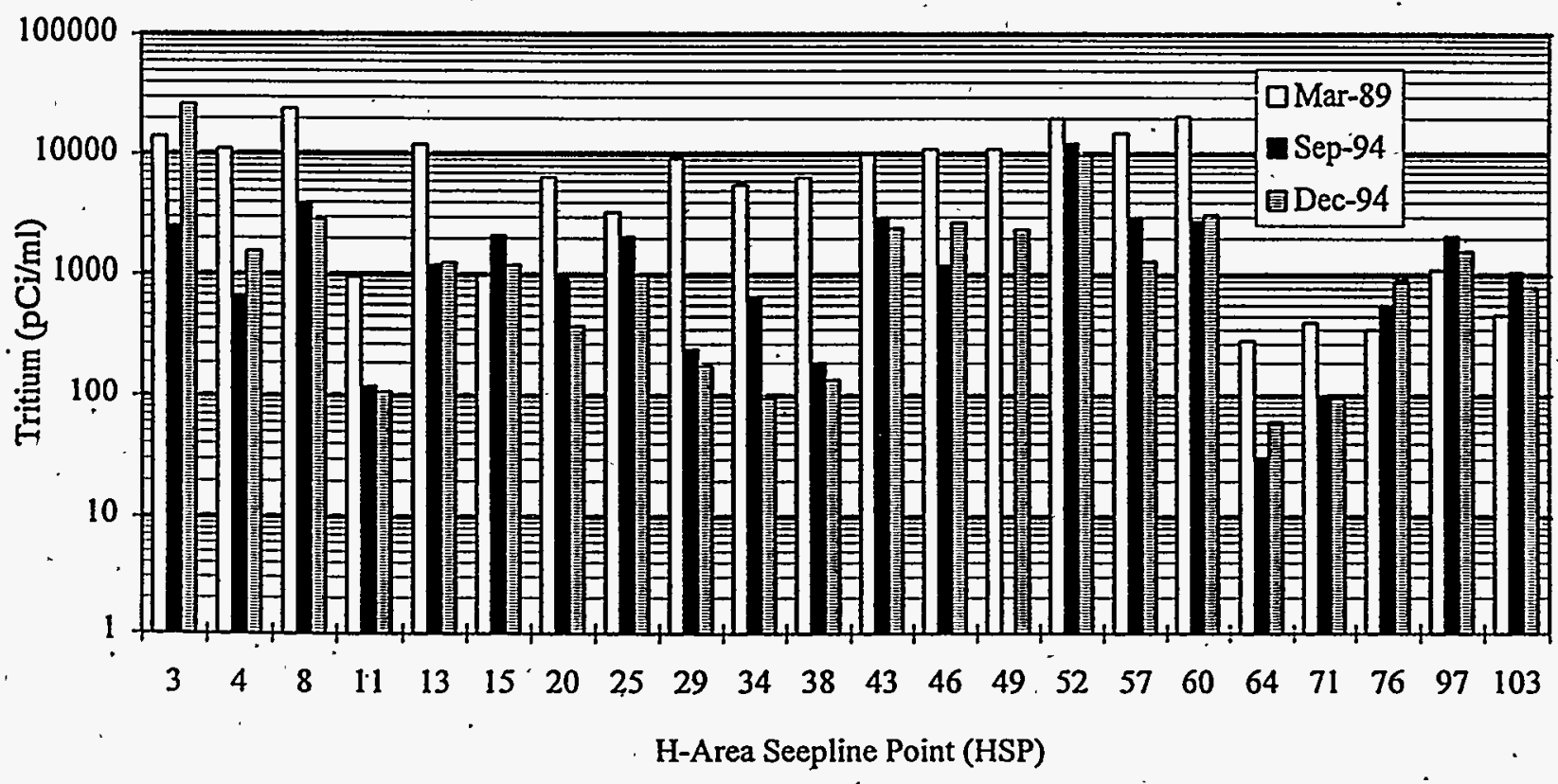

Figure 8. Comparisón of Tritium Measurements for Selected H-Area Seepline Locations 


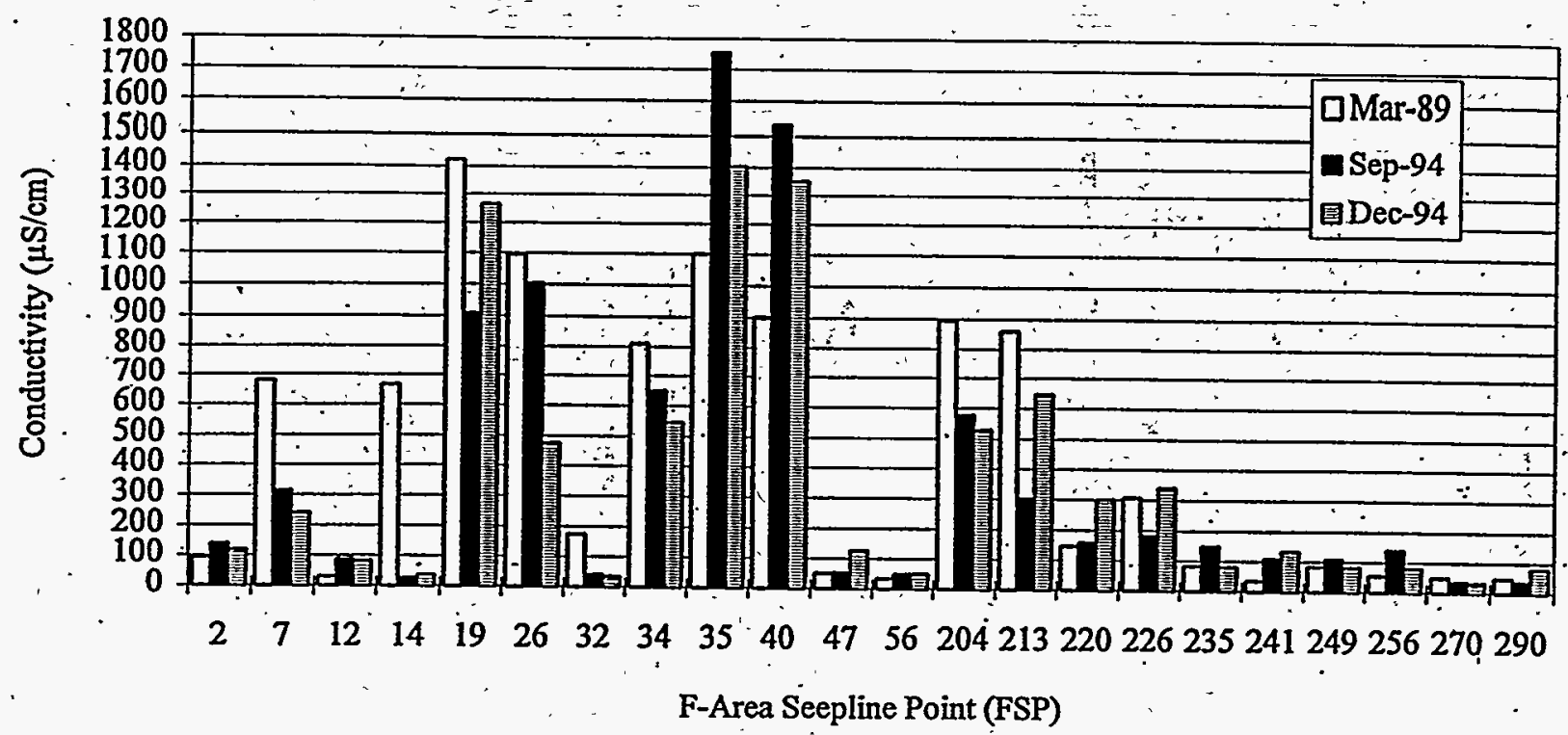

Figure 9. Comparison of Conductivity Measurements for Selected F-Area Seepline Location

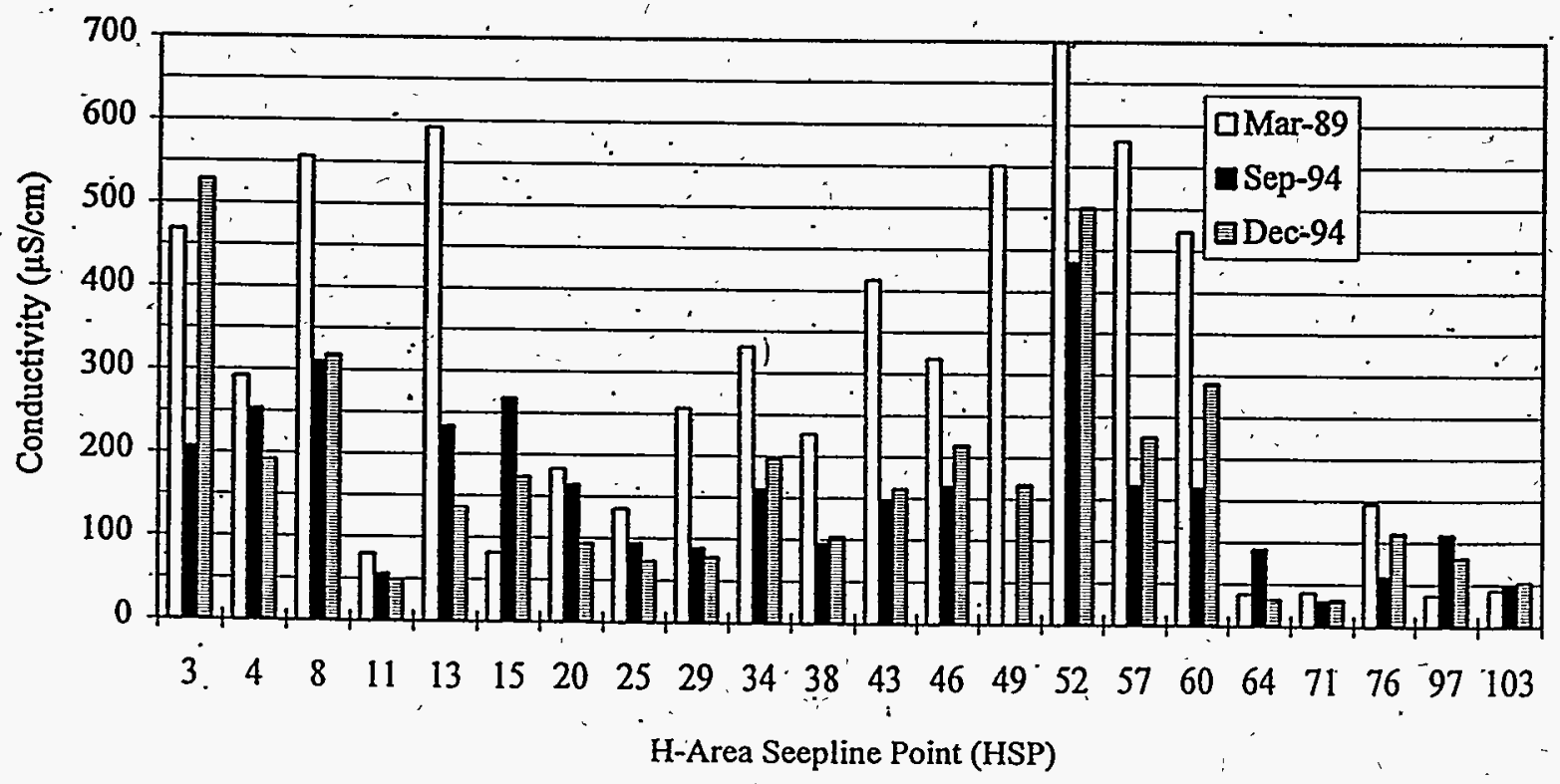

Figure 10. Comparison of Conductivity Measurements for Selected H-Area Seepline Locations. 


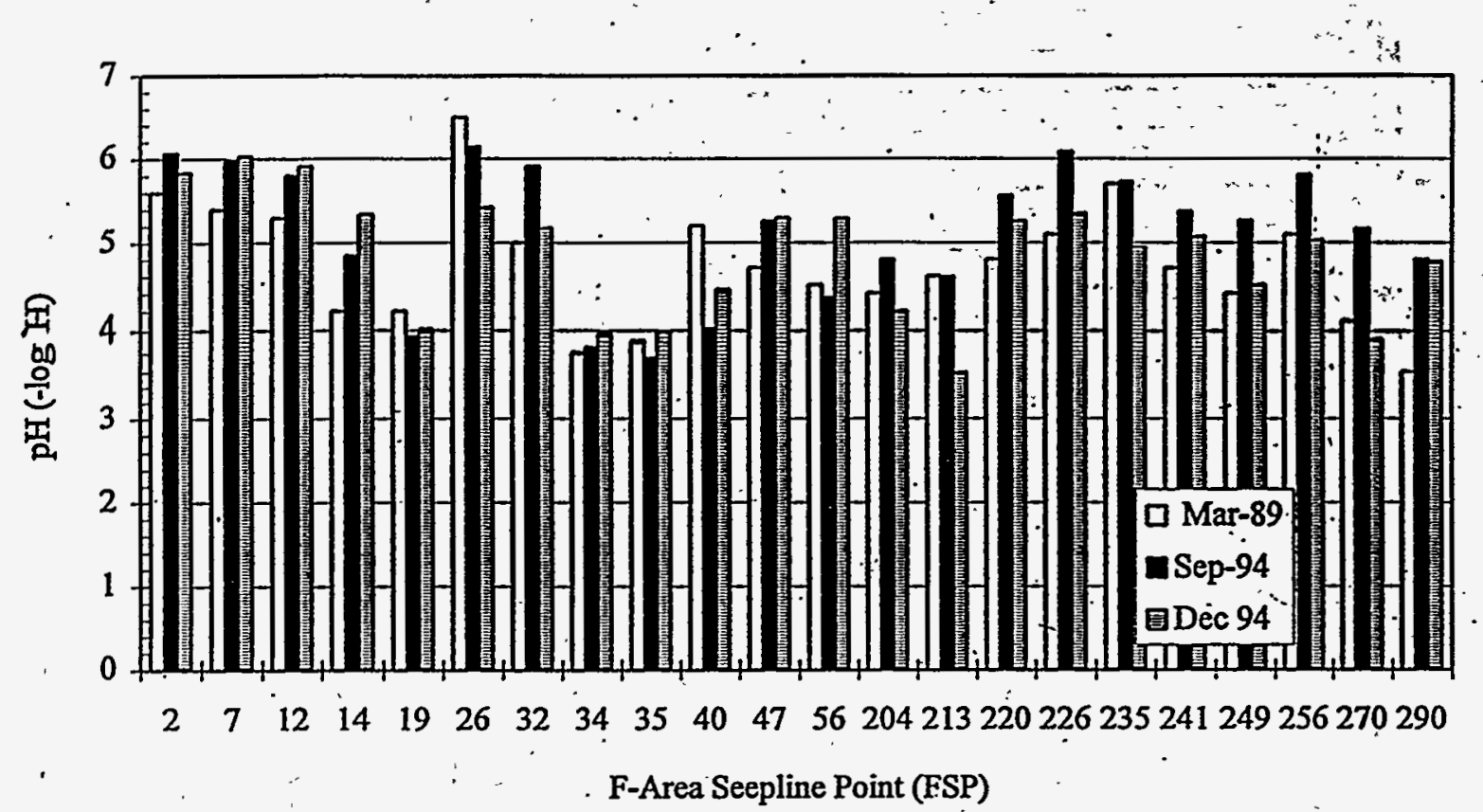

Figure 11. Comparison of $\mathrm{pH}$ Measurements for Selected F-Area Seepline Locations

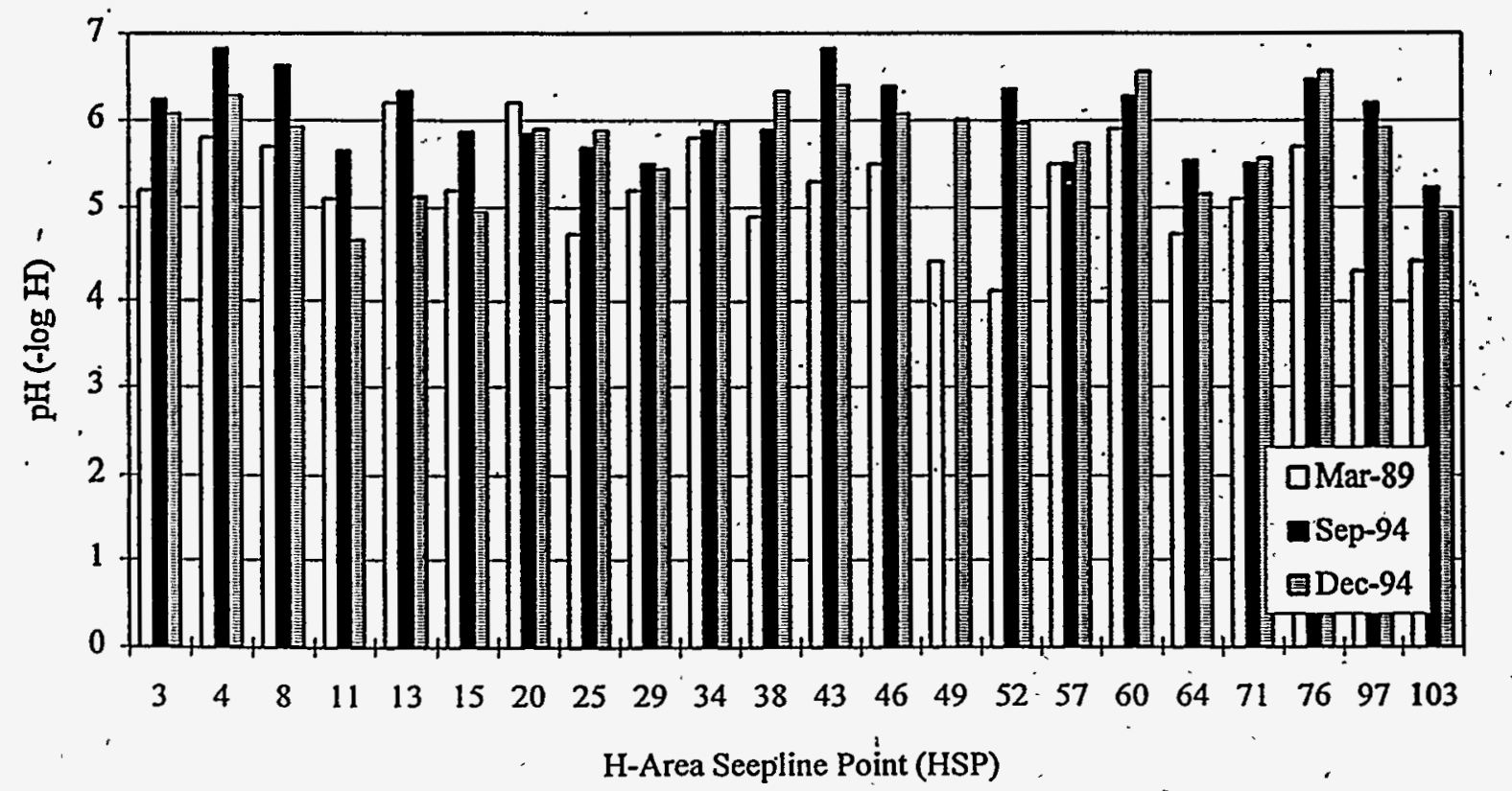

Figure 12, Comparison of $\mathrm{pH}$ Measurements for Selected H-Area Locations 


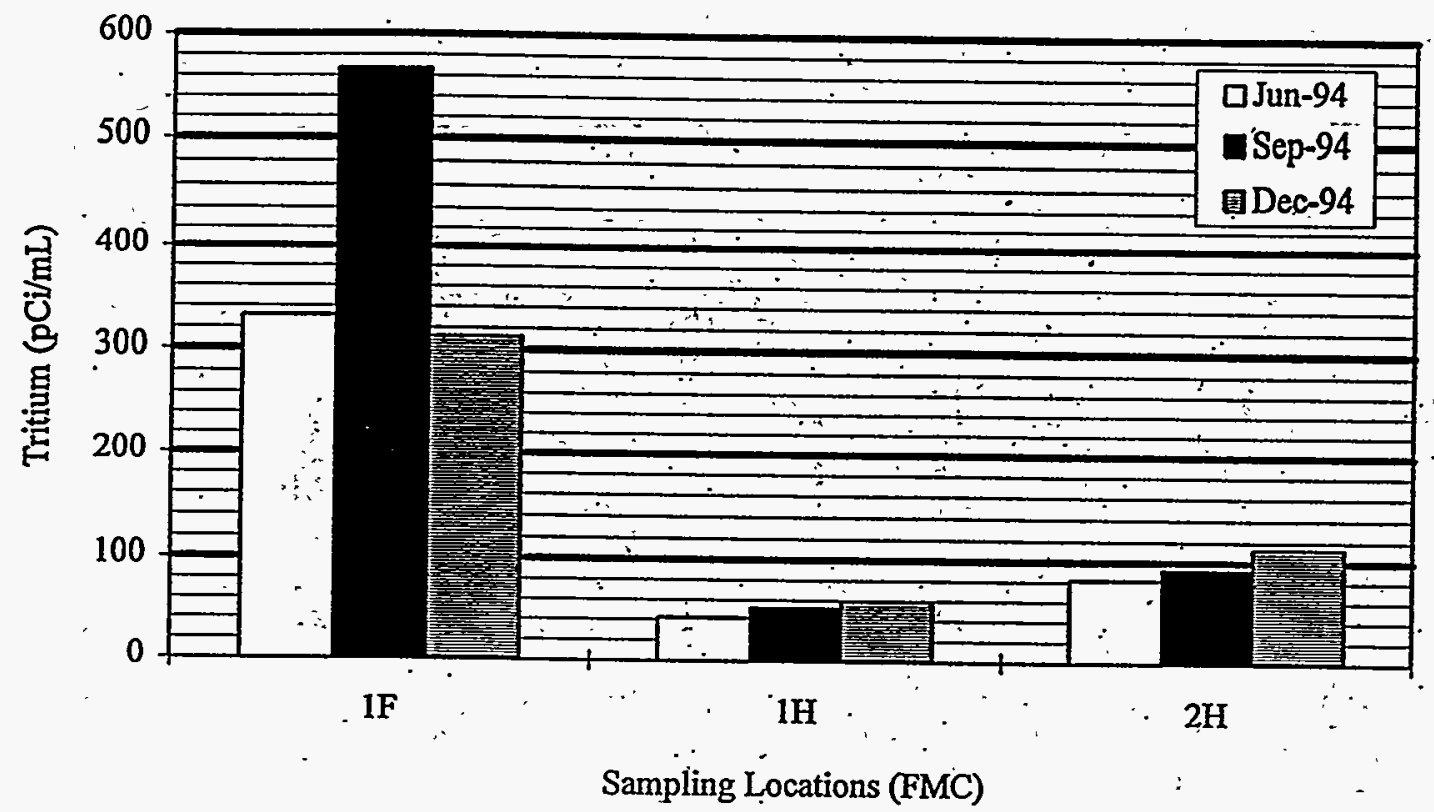

Figure 13. Comparison of Tritium ' Concentrations for Selected Fourmile Branch Locations

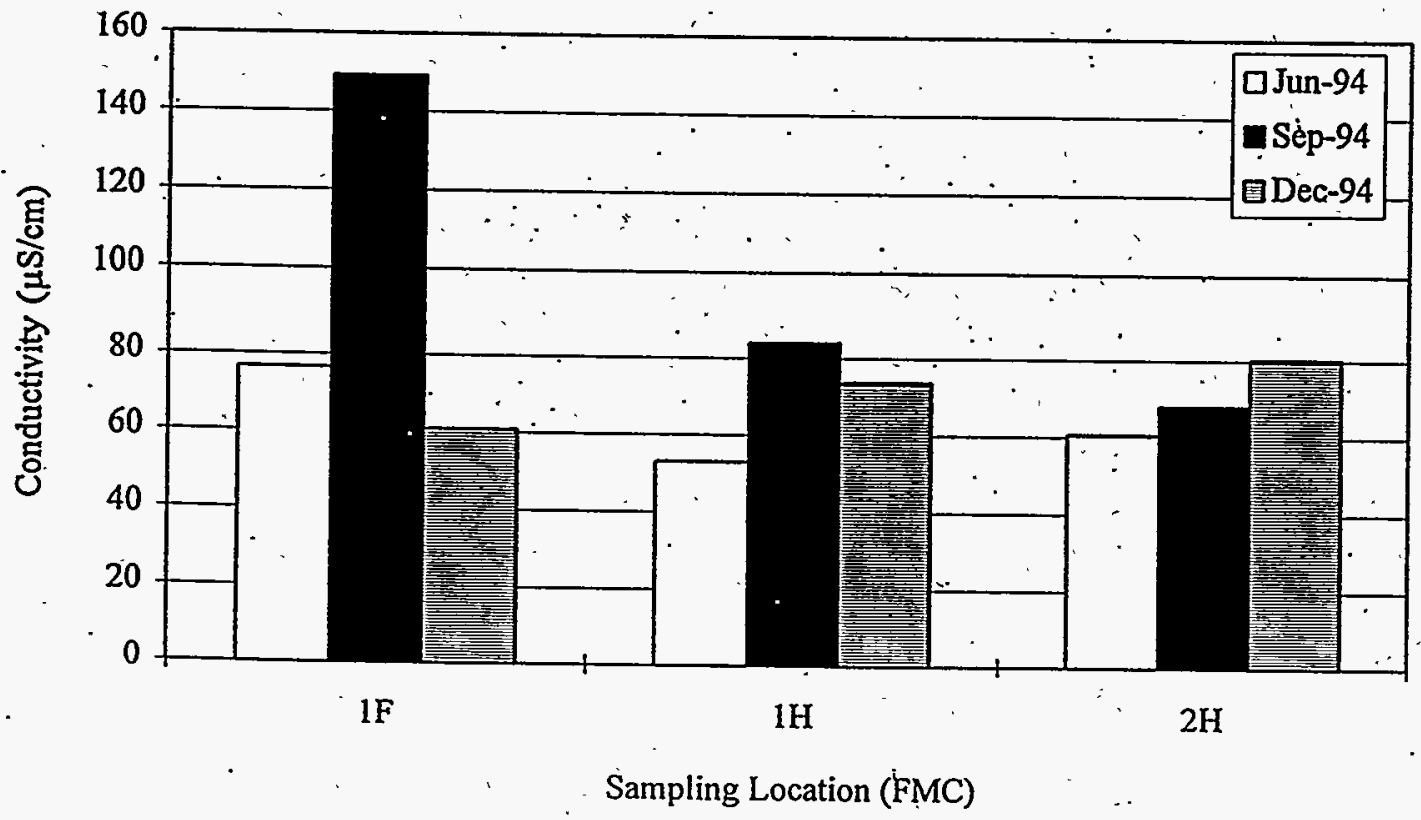

Figure 14. Comparison of Conductivity Measurements for Selected Fourmile Branch Locations 


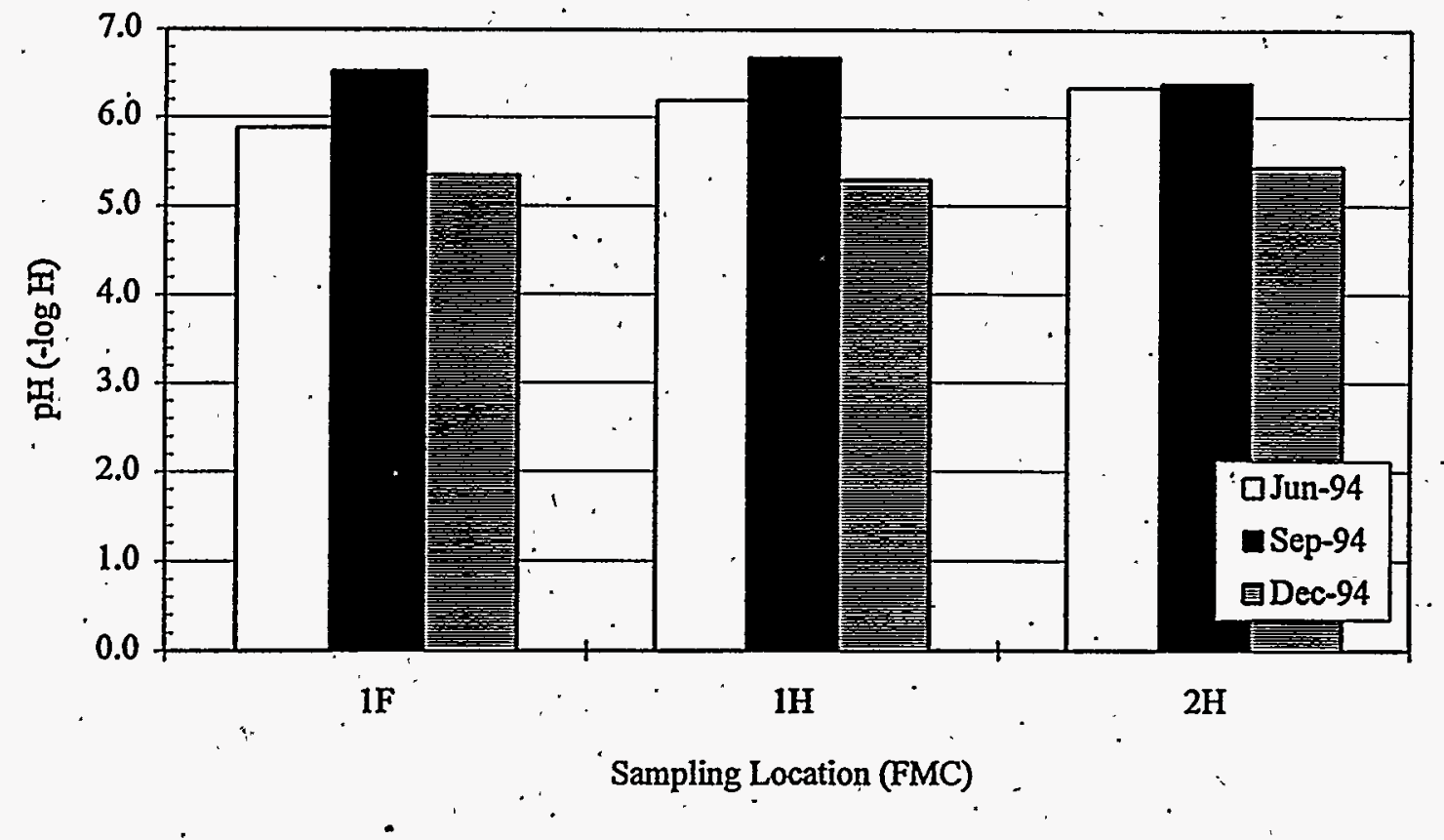

Figure 15. Comparison of pH Measurements for Selected Fourmile Branch Locations.

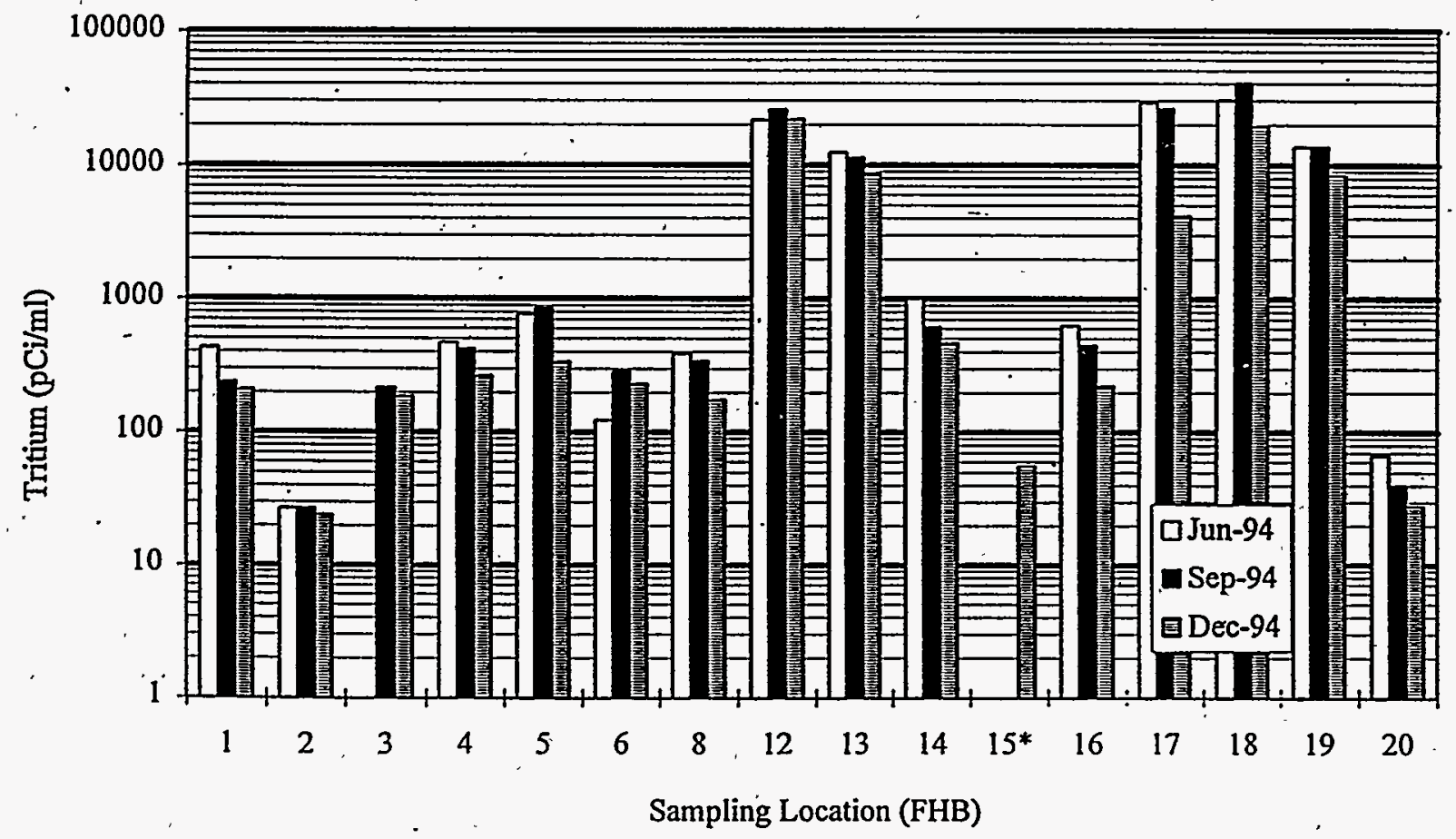

Figure 16. Comparison of Tritium Concentrations for Selected Locations on the Seepline South of 643-E * dry location June and September 1994 


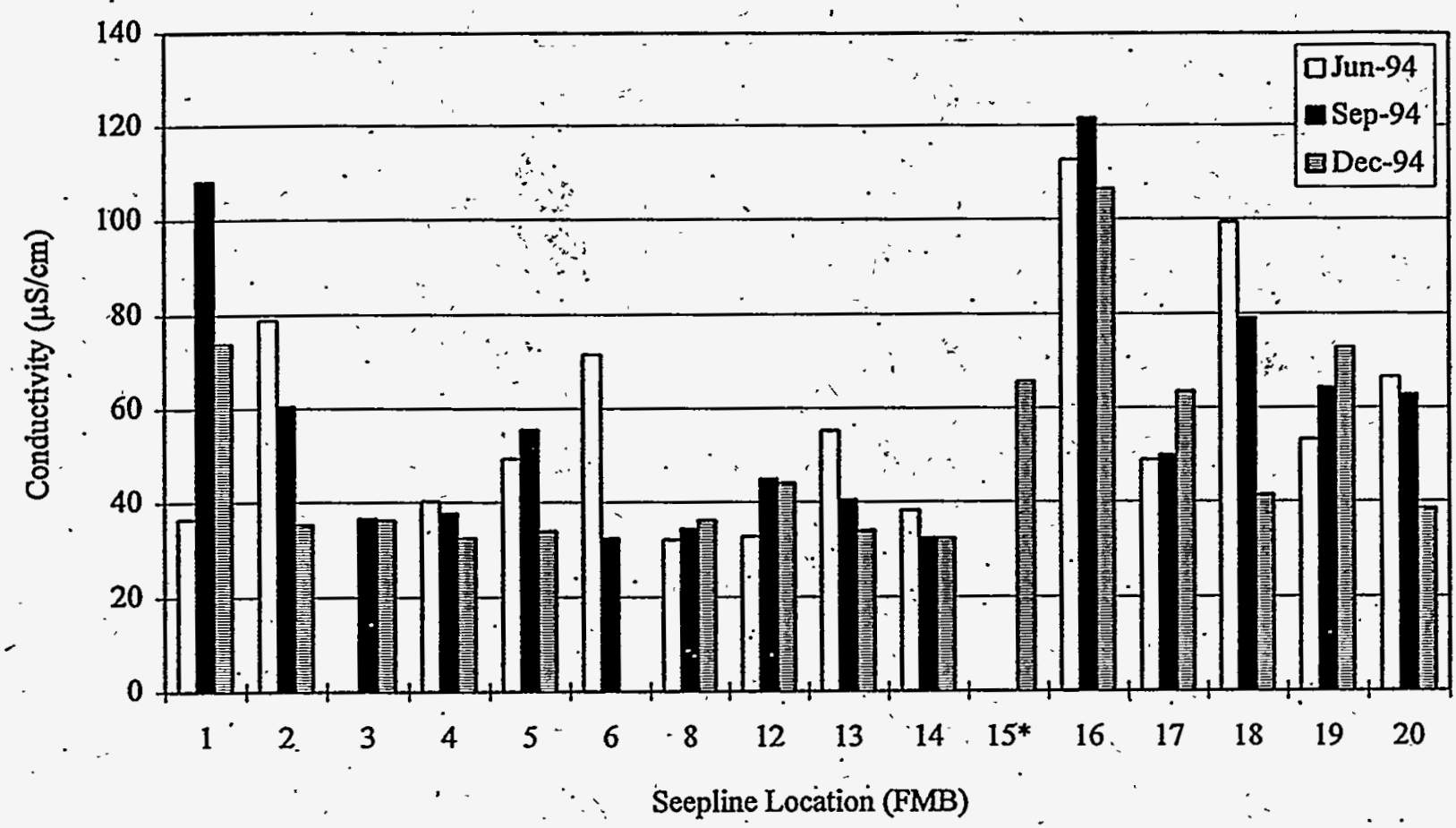

Figure 17. Comparison of Conductivity Concentrations for Selected Locations on the Seepline South of 643-E

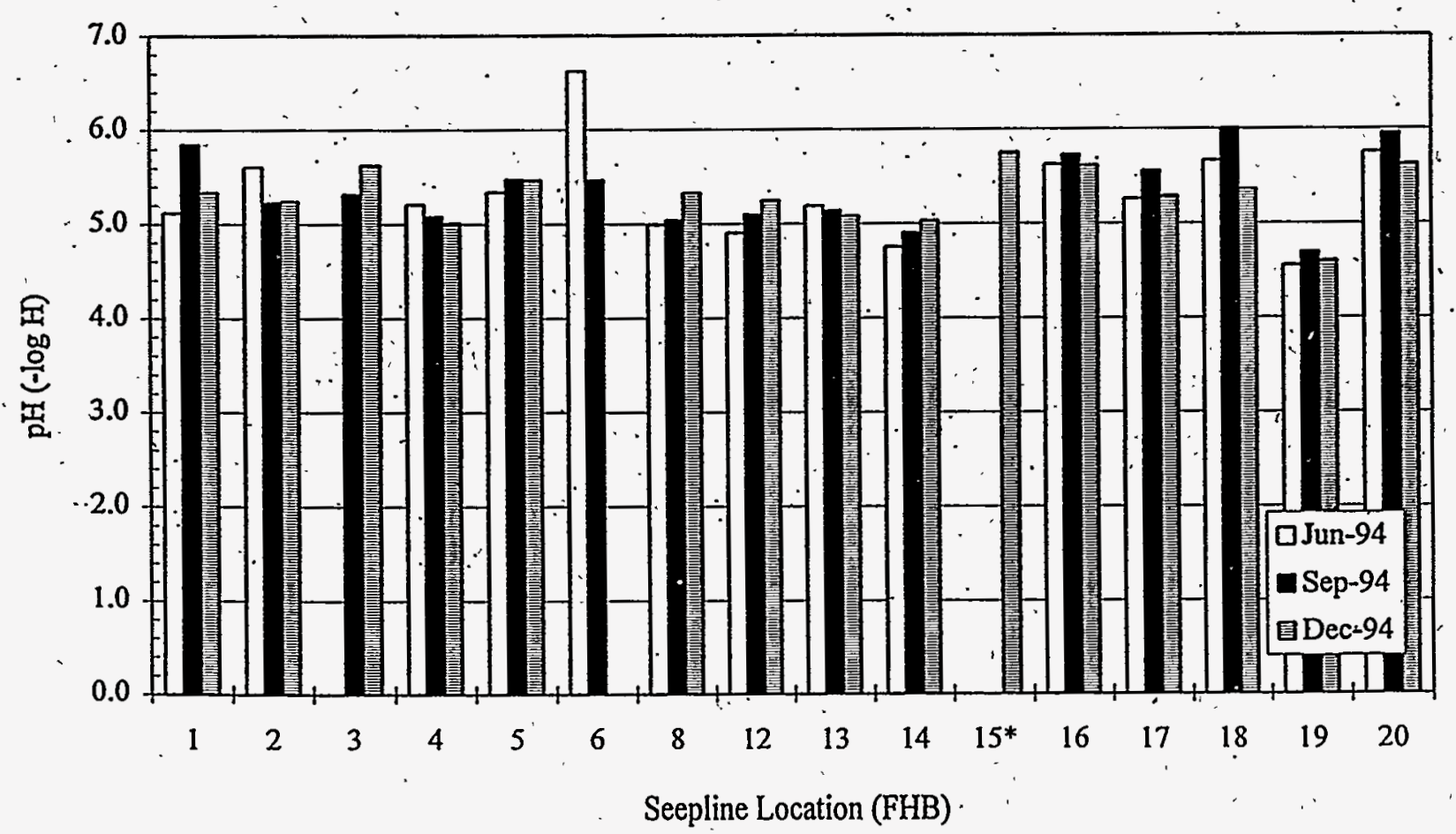

Figure 18. Comparison of pH Concentrations for Selected Locations on the Seepline South of 643-E

* dry location June and September 1994 
Table 1. Comparison of 1994 Monthly Rainfall to the Long Term Average Rainfall (1960-1991) from the F-Area Weather Station

\begin{tabular}{|c|c|c|c|c|c|}
\hline Month & \multicolumn{3}{|c|}{ 1994 Rainfall } & \multicolumn{2}{|c|}{ Long-Term } \\
\hline & & (cm) & \multicolumn{2}{|c|}{ Rainfall (cm) } \\
\hline January & 12.2 & & 11.8 & \\
\hline February & & 8.9 & & 10.8 & \\
\hline March & 17 & & 13.3 & \\
\hline April & 2.5 & & 8.6 & \\
\hline May & & 3.1 & & 10.7 & \\
\hline June & 12.2 & & 10.9. & \\
\hline July & 14.1 & & 14.3 & \\
\hline August & 3.2 & & 14.3 & \\
\hline September & 3.8 & & 9.5 & \\
\hline October & -26.7 & & 5.7 & \\
\hline November & 6.5 & & 6.6 & \\
\hline December & 12.5 & & 9.5 & \\
\hline
\end{tabular}

Table 2. Comparison of F-Area Seepline Measurements for Tritium, Conductivity, and pH for the March 1989, September 1994, and December 1994 Sampling Events.

\begin{tabular}{|c|c|c|c|c|c|c|c|c|c|}
\hline & \multicolumn{3}{|c|}{ Tritium (pCi/ml) } & \multicolumn{3}{|c|}{ Conductivity $(\mu \mathrm{S} / \mathrm{cm})$} & \multicolumn{3}{|c|}{$\mathrm{pH}(-\log \mathrm{H})$} \\
\hline Location & Mar-89 & Sep-94 & Dec-94 & Mar-89 & Sep-94 & Dec-94 & Mar-89 & Sep-94 & Dec-94 \\
\hline 2 & 520 & 723. & 381 & 94. & 139 & 119 & 5.6 & 6.1 & 5.8 \\
\hline 7 & 3400 & 978 & 1270 & 681 & 314 & 242 & 5.4 & 6.0 & 6.0 \\
\hline 12 & 260 & 162 & 103 & 30 & 90 & 84 & 5.3 & 5.8 & 5.9 \\
\hline 14 & 14000 & 27 & 16 & 666 & 27 & 37 & 4.2 & 4.9 & 5.3 \\
\hline 19 & 4900 & 3514 & 6300 & 1424 & 909 & 1265 & 4.2 & 4.0 & 4.0 \\
\hline 26 & 4400 & 2460 & 2020 & 1095 & 1004 & 476 & 6.5 & 6.1 & 5.4 \\
\hline 32 & 3600 & 53 & 46 & 174 & 42 & 35 & 5.0 & 5.9 & 5.2 \\
\hline 34 & 14000 & 3893 & 3040 & 810 & 650 & 545 & 3.8 & 3.9 & 4.0 \\
\hline 35 & 11000 & 12220 & 7810 & .1100 & 1755 & 1404 & 3.9 & 3.8 & 4.0 \\
\hline 40 & 7800 & 7394 & 6410 & 900 & 1533 & 1352 & 5.2 & 4.0 & 4.4 \\
\hline 47 & 100 & 28 & 17 & $52^{\circ}$ & 54 & 126 & 4.7 & 5.3 & 5.3 \\
\hline 56 & 19 & 9 & 12 & 34 & 50 & 50 & 4.5 & 4.4 & 5.3 \\
\hline 204 & 3000 & 2054 & 3210 & 895 & 577 & 528 & 4.4 & 4.8 & 4.2 \\
\hline 213 & 2800 & 2818 & 3050 & 860 & 302 & 647 & 4.6 & 4.6 & 3.6 \\
\hline 220 & 560 & 659 & 984 & 147 & 159 & 300 & 4.8 & 5.6 & 5.3 \\
\hline 226 & 1300 & 616 & 1110 & 306 & .185 & 339 & 5.1 & 6.1 & 5.4 \\
\hline 235 & 580 & 442 & 410 & 84 & 149 & 82 & 5.7 & 5.7 & 5.0 \\
\hline 241 & 560 & 637 & 585 & 36 & 109 & 133 & 4.7 & 5.4 & 5.1 \\
\hline 249 & 580 & 344 & - 301 & 84 & 109 & 84 & 4.4 & 5.3 & 4.5 \\
\hline 256 & 400 & 584 & 187 & 56 & 141 & 82 & 5.1 & 5.8 & 5.0 \\
\hline $270^{\circ}$ & 40 & 70 & 58 & 50 & 38 & 33 & 4.1 & 5.2 & 3.9 \\
\hline 290 & 35 & 46 & 31 & 49 & 38 & 81 & 3.6 & 4.8 & 4.8 \\
\hline
\end{tabular}


Table 3. Comparison of H-Area Seepline Measurements for Tritium; Conductivity, and pH for the March .1989, September 1994, and December 1994 Sampling Events.

\begin{tabular}{|c|c|c|c|c|c|c|c|c|}
\hline \multicolumn{3}{|c|}{ Tritium (pCi/ml) } & \multicolumn{3}{|c|}{ Conductivity $(\mu \mathrm{S} / \mathrm{cm})$} & \multicolumn{3}{|c|}{ pH $(-\log \mathrm{H})$} \\
\hline Mar-89. & Sep-94 & Dec-94. & Mar 89 & Sep-94 & Dec-94 & Mar-89 & Sep-94 & Dec-94- \\
\hline 14000 & 2510 & 26400 & 468 & 207 & 528 & 5.2 & 6.2 & 6.1 \\
\hline 11000 & 694 & 1550 & 292 & 253 & 191 & 5.8 & 6.8 & 6.3 \\
\hline 24000 & 3975 & 2850 & 556 & 310 & 318 & 5.7 & 6.6 & 5.9 \\
\hline 960 & 123 & 109 & 80 & 56 & 49 & 5.1 & 5.7 & 4.6 \\
\hline 12000 & 1210 & 1260 & 592 & $234^{\prime}$ & 136 & $\overline{6.2}$ & 6.3 & 5.1 \\
\hline 1000 & 2101 & 1200 & 82 & 268 . & 173 & 5.2 & 5.9 & 5.0 \\
\hline 6500 & 917 & 421 & 183 & 164 & 94 & 6.2 & 5.9 & 5.9 \\
\hline 3300 & 2060 & 1010 & 135 & 95 & 73. & 4.7 & 5.7 & 5.9 \\
\hline 9200 & 273 & 187 & 257 & 89 & 78 & 5.2 & 5.5 & 5.4 \\
\hline 5600 & 691 & 94 & 331 & .161 & 197. & 5.8 & 5.9 & 6.0 \\
\hline 6500 & 202 & 141 & 227 & 96 & 103 & 4.9 & 5.9 & $\overline{6.3}$ \\
\hline 10000 & 2990 & 2430 & 413. & 148 & 161 & 5.3 & 6.8 & $\overline{6.4}$ \\
\hline 11000 & 1204 & 2740 & 318 & 165 & $214^{\circ}$ & 5.5 & 6.4 & 6.1 \\
\hline 11000 & dry & 2360 & 551 & dry & 167 & 4.4 & dry & 6.0 \\
\hline 20000 & 12372 & 9710 & 699 & 436 & 501 & $\overline{4.1}$ & 6.4 & 6.0 \\
\hline 15000 & 2996 & 1300 & 581 & 167 & 226 & 5.5 & 5.5 & 5.7 \\
\hline 21000 & 2821 & 3150. & 473 & 165 & .290 & 5.9 & 6.3 & 6.6 \\
\hline 320 & 31 & 61 & 38 & 92 & 32 & 4.7 & 5.5 & 5.2 \\
\hline 450 & 97. & 97 & 40 & 30 & 31 & 5.1 & 5.5 & 5.6 . \\
\hline 400 & 598 & 907 & 146 & 59 & 111 & 5.7 & 6.5 & 6.6 \\
\hline 1100 & 2093 & 1570 & 37 & 109 & 82 & 4.3 & 6.2 & 5.9 \\
\hline 510 & 1060 & 807 & 43 & .49 & 52 & 4.4 & 5.2 & 5.0 \\
\hline
\end{tabular}

Table 4. Comparison of Fourmile Branch Stream Measurements for Tritium, Conductivity, and pH for the June 1994, September 1994, and December 1994 Sampling Events.

\begin{tabular}{|c|c|c|c|c|c|c|c|c|c|}
\hline & \multicolumn{3}{|c|}{ Tritium (pCi/mI } & \multicolumn{3}{c|}{ Conductivity $(\mu \mathrm{S} / \mathrm{cm})$} & $\ddots$ & pH (-log H) \\
\hline Location & Jun-94 & Sep-94 & Dec-94 & Jun-94 & Sep-94 & Dec-94 & Jun-94 & Sep-94 & Dec-94 \\
\hline 1F & 331 & 567 & 312 & 76 & 149 & 61 & 5.9 & 6.5 & 5.3 \\
\hline 1H & 42 & 52 & 59 & 53 & 84 & 73 & 6.2 & 6.7 & 5.3 \\
\hline 2H & 82 & 93 & 113 & 61 & 68 & 80 & 6.3 & 6.4 & 5.4 \\
\hline
\end{tabular}


Table 5. Comparison of 643-E Seepline Measurements for Tritium, Conductivity, and pH for the June 1994, September 1994, and December 1994 Sampling Events.

\begin{tabular}{|c|c|c|c|c|c|c|c|c|c|}
\hline & \multicolumn{3}{|c|}{ Tritium (pCi/ml) } & \multicolumn{3}{c|}{ Conductivity ( $\mu$ S/cm) } & \multicolumn{3}{c|}{ pH (-log H) } \\
\hline Location & Jun-94 & Sep-94 & Dec-94 & Jun-94 & Sep-94 & Dec-94 & Jun-94 & Sep-94 & Dec-94 \\
\hline 1 & 427 & 236 & 553 & .36 & 108 & 91 & 5.1 & 5.9 & 5.4 \\
\hline 2 & 27 & 27 & 25 & 79 & 60 & 51 & 5.6 & 5.2 & 5.0 \\
\hline 3 & dry & 217 & 370 & dry & 37 & 40 & dry & 5.3 & 5.3 \\
\hline 4 & 471 & 421 & 785 & 40 & 38 & 40 & 5.2 & 5.1 & 5.1 \\
\hline 5 & 769 & 858 & 907 & 49 & 56 & 40 & 5.3 & 5.5 & 5.0 \\
\hline 6 & 124 & 285 & 378 & 71 & 32 & 33 & 6.6 & 5.5 & 5.1 \\
\hline 8 & 386 & 342 & 419 & 32 & 34 & 32 & 5.0 & 5.0 & 4.5 \\
\hline $12 * *$ & 21700 & 25739 & 18738 & 33 & 45 & 40 & 4.9 & 5.1 & 5.0 \\
\hline 13 & 12500 & 11381 & 13762 & 55 & 40 & 46 & 5.2 & 5.1 & 5.3 \\
\hline 14 & 1010 & 614 & 939 & 38 & 32 & 34 & 4.8 & 4.9 & 4.9 \\
\hline 15 & dry & dry & 315 & dry & dry & 187 & dry & dry & 5.7 \\
\hline 16 & 632 & 445 & 785 & 113 & 122 & 117 & 5.6 & 5.7 & 5.3 \\
\hline 17 & 29100 & 26193 & 36383 & 49 & 50 & 57 & 5.3 & 5.6 & 5.2 \\
\hline 18 & 30300 & 40396 & 25966 & 99 & 79 & 102 & 5.7 & 6.0 & 5.3 \\
\hline 19 & 13800 & 13784 & 30537 & 53 & 64 & 55 & 4.6 & 4.7 & 4.1 \\
\hline 20 & 67 & 40 & 42 & 66 & 63 & 125 & 5.8 & 6.0 & 5.8 \\
\hline
\end{tabular}

**Stream sample location

nd: no data in log book on this location dry: no sample 